\title{
RAZLIKOVANJE ZNAČENJA I UPORABA ENGLESKIH PRIDJEVA NA -IC I -ICAL MEĐU HRVATSKIM GOVORNICIMA ENGLESKOGA JEZIKA
}

\author{
Sanja Škifić \\ Sveučilište u Zadru
}

Engleski se jezik kao lingua franca obrađuje s različitih stajališta $\mathbf{i}$ u različitim kontekstima. Takva istraživanja uključuju, između ostaloga, aspekte učenja i uporabe engleskoga jezika među neizvornim govornicima u kontekstima gdje se engleski jezik tradicionalno poučava i rabi kao strani jezik. Ovaj se rad bavi istraživanjem razlikovanja značenja i uporabe engleskih pridjeva na -ic i -ical među hrvatskim govornicima engleskoga jezika. Cilj je opisati uporabu takvih pridjeva te utvrditi mjeru u kojoj neizvorni govornici engleskoga jezika razlikuju njihova značenja. Odabir pridjeva kao i pregled značenjskih razlika među njima temelje se ponajprije na monografiji koju je 2007. godine objavio Mark Kaunisto te na mrežnom izdanju Oxfordova rječnika engleskoga jezika. Istraživanje koje je uključivalo primjenu testa provedeno je u ožujku i travnju 2019. godine među devedeset $i$ šest hrvatskih studenata anglistike. Rezultati istraživanja ukazuju na to da razlikovanje značenja engleskih pridjeva na -ic i -ical ovisi ponajprije o samoj razlici u značenjima ponuđenih pridjeva, učestalosti uporabe određenoga pridjeva u engleskome jeziku te o jezičnome okruženju u kojemu se pridjev rabi.

Ključne riječi: engleski jezik, pridjevi na -ic i-ical, kolokacije, sinonimija, neizvorni govornici.

\section{UVOD}

Širenje engleskoga jezika diljem svijeta dovelo je, između ostaloga, i do promjena u njegovu statusu u kontekstima koji nisu dominantno anglofoni, odnosno u zemljama u kojima engleski nije de facto ili de iure službeni jezik. Hrvatska je, kao i mnoge druge zemlje, država u kojoj se engleski jezik tradicionalno poučava i rabi kao strani jezik. Međutim, s obzirom na najrecentnija tehnološka i telekomunikacijska postignuća koja iz dana u dan omogućuju sve brže i učestalije kretanje ljudi i razmjenu informacija na globalnoj razini te s obzirom na izloženost raznim oblicima medija, učestalost uporabe engleskoga jezika $u$ zemljama $u$ kojima se tradicionalno smatra stranim jezikom $\mathrm{u}$ znatnom je porastu. Takve su promjene s lingvističkoga stajališta dovele do preispitivanja statusa engleskoga jezika kao stranoga ili pak drugoga jezika, a u odnosu na druge koji se u Hrvatskoj nesumnjivo mogu smatrati stranim jezicima (v. Mihaljević Djigunović i Geld, 2002).

\footnotetext{
sskific@unizd.hr
} 
Porast uporabe engleskoga jezika te sve veći standardi i zahtjevi poznavanja engleskoga jezika koji se postavljaju pred hrvatske govornike, a posebice studente anglistike, navode na promišljanje o strukturama engleskoga jezika čije razlikovanje i uporaba mogu predstavljati izazov neizvornim govornicima engleskoga jezika.

Ovaj se rad bavi razlikovanjem značenja i uporabom engleskih pridjeva na -ic i -ical među hrvatskim govornicima engleskoga jezika. Polazimo od pretpostavke da će uspješnost razlikovanja strukturno sličnih i značenjski bliskih engleskih pridjeva ovisiti ponajprije o razlici između njihovih značenja, učestalosti uporabe te o jezičnome okruženju u kojemu se pridjev rabi. Mjera u kojoj se engleski pridjevi na -ic i -ical značenjski razlikuju varira od slučaja do slučaja, a autori se u utvrđivanju razlika ne oslanjaju samo na leksikografske unose, već i na druge vrste korpusa koji svjedoče o uporabi takvih pridjeva u različitim jezičnim okruženjima (v. Kaunisto, 2007). Kada govorimo o jezičnome okruženju u kojemu se pridjev rabi, govorimo ponajprije o pridjevima kao dijelovima kolokacija.

Kao modifikatori ${ }^{1}$ unutar imenskih skupina, pridjevi se nerijetko istražuju kao sastavni dijelovi pridjevno-imeničkih kolokacija. Kolokacije se javljaju na sintagmatskoj jezičnoj razini, a ona uključuje cijeli niz pojavnosti koje se mogu proučavati s različitih stajališta. Sukladno tome, Tucker (1998: 11) naglašava važnost uočavanja razlike između rasprave o kolokacijama koje uključuju vjerojatnost pojave jednog leksema u sintagmatskom okruženju drugih leksema te rasprave o sintagmatskim odnosima između strukturnih dijelova u gramatičkoj jedinici.

Kolokacije predstavljaju izrazito zanimljivo i produktivno područje lingvističkih istraživanja, a mogu se analizirati s različitih stajališta te unutar jednoga jezika ili usporedno, u dva ili više jezika. Takva su istraživanja $u$ velikoj mjeri smještena unutar područja usvajanja i poučavanja drugoga (J2) jezika. To je razumljivo s obzirom na poteškoće na koje pojedinci kojima određeni jezik nije materinski nailaze pri usvajanju višejezičnih izraza koji su u različitoj mjeri fiksni te se kao takvi moraju usvajati. Štoviše, mjera uspješnog usvajanja kolokacija smatra se jednim od temeljnih pokazatelja mjere uspješnog usvajanja drugoga jezika (Men, 2018: 9). U raspravi o elicitacijskim istraživanjima Nesselhauf (2005: 4) navodi kako je u većini takvih istraživanja razumijevanje kolokacija u drugom planu u odnosu na produkciju kolokacija, a stoga što, $u$ odnosu na produkciju, razumijevanje ne predstavlja tako velik problem u procesu učenja. Razlog tome može se potražiti u samom viđenju prirode kolokacija, koje seu određenim slučajevima poimaju kao fiksni izrazi koje pojedinci moraju usvojiti kao takve. Mjera u

\footnotetext{
${ }^{1}$ U ovome se radu izraz 'modifikator' rabi u značenju u kojemu se u engleskome jeziku rabi izraz 'modifier'. O razlikama između uporabe engleskoga izraza 'modifier' i uporabe hrvatskoga izraza 'modifikator' s lingvističkoga stajališta v. Zergollern-Miletić (2008: 47).
} 
kojoj kolokacije možemo smatrati fiksnim izrazima do određene je mjere relativna. Tako, primjerice, Howarth (1998) i Nesselhauf (2003) predstavljaju svoja viđenja klasifikacije višejezičnih izraza, a ovisno o stupnjevanju snage veze, odnosno restrikcije između sastavnica izraza. Semantički gledano, o kolokacijama se može raspravljati sa stajališta značenjske transparentnosti, ${ }^{2}$ ali i o mogućnostima zamjene jednog elementa u kolokaciji s drugim koji predstavlja njegov sinonim. Kao što će biti vidljivo u dijelu rada u kojem se iznose rezultati istraživanja, pojam kolokacije je iznimno bitan pri analizi razlikovanja značenja i uporabe engleskih pridjeva na -ic i -ical.

\section{SINONIMIJA I PRIDJEVI - USVAJANJE STRUKTURNO SLIČNIH I ZNAČENJSKI BLISKIH IZRAZA}

Rasprave o temeljnim značenjskim odnosima koji se $u$ jeziku mogu identificirati nezaobilazno uključuju i analizu sinonimije. Unutar takvih rasprava pitanje (ne)postojanja potpune sinonimije zauzima jedno od središnjih mjesta. Pojam potpune sinonimije i mogućnosti njegove analize usko su vezani uz pojam kolokacije. Primjerice, Palmer (1981: 63) navodi proces supstitucije kao jedan od mogućih testova za potpunu sinonimiju, ali pri tome ustvrđuje i kako je takav test samo naznaka kolokacijskih mogućnosti, a ne nužno i mjere preklapanja značenja pojedinih izraza. ${ }^{3}$ Činjenicu da kolokacijska restrikcija predstavlja središnju, ali ne i jedinu indikaciju za identifikaciju i analizu djelomičnih sinonima Palmer (1981: 60-63) potvrđuje i klasifikacijom načina na koje se sinonimi mogu razlikovati, pri čemu kolokacijsku restrikciju navodi kao jednu od (najmanje) ${ }^{4}$ pet mogućih načina na koje se sinonimi mogu razlikovati. Tome u prilog ide i viđenje potpunih (odnosno apsolutnih) sinonima ${ }^{5}$ kao izraza koji se preklapaju u svim kontekstualnim odnosima, ${ }^{6}$ pri čemu možemo govoriti o „relativnoj normalnosti” (Cruse, 1986: 268). Iz navedenoga je vidljivo da je pitanje potpune sinonimije ponajprije vezano uz pitanje konteksta, a tek posredstvom njega i uz pitanje kolokacije.

Gledhill (2000: 7-17) pruža pregled tri različite perspektive unutar kojih se kolokacije istražuju, a to su: statistička/tekstualna, semantička/sintaktička

\footnotetext{
${ }^{2}$ Primjerice, kao jedno od obilježja kolokacija Nesselhauf (2003: 223) ističe to da su „prilično transparentne" (fairly transparent).

3 "What we shall find, of course, is that some words are interchangeable in certain environments only, e.g. that 'deep' or 'profound' may be used with 'sympathy' but only 'deep' with 'water', (...). But this will give us little measure of synonymy or of similarity of meaning; it will merely indicate the collocational possibilities, and these do not seem necessarily to be always closely related to nearness of meaning". (Palmer, 1981: 63)

4 "If we look at possible synonyms there are at least five ways in which they can be seen to differ". (Palmer, 1981: 60)

${ }^{5}$ Cruse (1986) koristi izraz 'absolute synonymy' ('apsolutna sinonimija').

${ }^{6}$ Cruse (1986: 268) se u navođenju takvog određenja potpunih (odnosno, prema njegovoj terminologiji, apsolutnih) sinonima oslanja na viđenje W. Haasa. Kontekstualna ekvivalentnost leksema se i u recentnijoj literaturi navodi kao temeljni kriterij za određenje potpunih (odnosno apsolutnih) sinonima (usp. Cruse, 2017: 243; Murphy, 2010: 110; Suau Jiménez, 2008: 162).
} 
te diskursna/retorička. Svaki je od navedenih pristupa obilježen osobitim poimanjem kolokacija i mogućnosti njihove analize, što je vidljivo iz samih naziva pristupa. Sve su tri perspektive iznimno bitne, a osobito $u$ analizi kolokacijskih parova u kojima je iznimno bitan kontekst, kao što je to slučaj s pridjevima kao modifikatorima unutar imenskih skupina, a osobito s onim pridjevima koji su strukturno slični, a mogu modificirati istu imenicu.

Pojedinci se pri učenju stranoga jezika susreću s različitim poteškoćama kada je riječ o usvajanju i ispravnoj uporabi pojedinih vrsta kolokacija, a te se poteškoće ne odnose samo na ispravan odabir jednog izraza umjesto drugog kako bi se proizvela kolokacija koja se kao takva rabi u ciljnom jeziku. U ovome kontekstu Lipka (1992: 167) osobito ističe dvije vrste problema. Prvi se odnosi na odabir između izraza koji pokazuju visok stupanj značenjske bliskosti (kao što je slučaj s engleskim large, big i great), a drugi na odabir izraza koji pokazuju strukturnu sličnost (kao što je slučaj s engleskim electric i electrical ili optic i optical). Očito je da se i kod određenih strukturno sličnih izraza može govoriti o izrazima koji su značenjski vrlo bliski. Međutim, upravo je njihova strukturna sličnost dodatan otežavajući čimbenik u razlikovanju i ispravnoj uporabi takvih izraza među neizvornim (a vjerojatno katkada i među izvornim) govornicima. Osim toga, s obzirom na to da se pojedinci pri usvajanju određenih izraza u stranome ili drugome jeziku nerijetko oslanjaju na materinski jezik, problemi mogu nastati i vezano uz taj aspekt kada se usvajaju određeni izrazi koji su u stranome jeziku strukturno slični (ali ne i identični), a koji se u materinskom jeziku prevode jednim te istim izrazom. Kao primjer tome može se navesti par historic i historical, dva izraza koji u engleskome jeziku pokazuju strukturnu sličnost i određenu razliku u značenju, ali se u hrvatskome jeziku prevode istim izrazom, i to bez obzira na kontekst, odnosno imenicu s kojom ulaze u kolokaciju. Možemo, stoga, uvjetno govoriti o olakšavajućoj okolnosti pri usvajanju izraza koji su samo značenjski bliski, ali ne i strukturno slični. U slučaju i takvih leksičkih jedinica, iste se u materinskom jeziku često mogu prevoditi istim izrazom. Međutim, upravo će kontekst, odnosno kolokacija utjecati na razliku u značenju, odnosno prijevodu. S druge strane, ponekad je izbor značenjski bliskih i strukturno različitih pridjeva uvjetovan jezičnim kontekstom koji je širi od same kolokacije koju čine pridjev i imenica. Ovdje možemo uzeti primjer engleskih pridjeva big i large. U raspravi o potpunim (odnosno apsolutnim) sinonimima Cruse (2000) navodi različite primjere koji ilustriraju problem identifikacije takvih sinonima ukoliko izrazi nisu zamjenjivi i prihvatljivi u svim kontekstima. Tako autor, između ostalih, navodi i sljedeće primjere: He's a big baby, isn't he? i He's a large baby, isn't he?, pri čemu je prvi izraz $\mathrm{u}$ ovome kontekstu prihvatljiviji, odnosno „relativno normalniji" (Cruse, 2000: 157). 


\section{ZNAČENJSKA I UPORABNA RAZLIKA IZMEĐU ENGLESKIH PRIDJEVA NA -IC I -ICAL}

$\mathrm{U}$ istraživanjima pridjeva naglasak može biti stavljen na pridjeve unutar jednoga jezika ili se kao cilj postavlja donošenje zaključaka na temelju korpusa iz više jezika. Sukladno tome, Cabredo Hofherr (2010: 16) raspravlja, između ostaloga, o mogućnostima analize razlika pridjeva u usporedbi više jezika, ali i unutar jednoga jezika. Kada je riječ o usporedbi pojedinih aspekata pridjeva u više jezika, moguće je navesti različite izvore koji se odnose na to područje. Tako, primjerice, Cinque (2010) nudi detaljnu usporednu analizu u kojoj se ponajprije usredotočuje na prikaz sintakse pridjeva unutar romanskog (talijanskog) i germanskog (engleskog) jezika, a Sleeman, Van de Velde i Perridon (2014) nude uredničku knjigu čiji su različiti prilozi objedinjeni temom pridjeva u germanskim i romanskim jezicima.

U ovome je radu naglasak stavljen na istraživanje značenjskih i uporabnih razlika odabranih parova engleskih pridjeva koji završavaju na -ic i -ical, dok je morfologija analiziranih pridjeva bitna utoliko što predstavljaju strukturno slične pridjeve.

\subsection{Istraživanja engleskih pridjeva na -ic $i$-ical}

Engleski pridjevi na -ic i -ical predstavljaju izrazito zanimljivo područje istraživanja, a može im se pristupiti s različitih stajališta. Lipka (1992: 166170) se na njih osvrće $u$ dijelu monografije u kojem raspravlja o „kolokaciji kao neutralnoj sintagmi". S druge strane, Gries se (2017) koristi metodama kvantitativne korpusne lingvistike za niz studija slučaja, uključujući i analizu frekvencije pridjeva na -ic i -ical (200-203) te frekvencije tih pridjeva u kolokacijama (210-212).

Kaunisto (2007) uzima dijakronijsku perspektivu te na temelju leksikografskih i niza drugih izvora pruža iscrpnu analizu promjena $u$ značenju i uporabi navedenih engleskih pridjeva. Upravo monografija naslovljena Variation and Change in the Lexicon: A Corpus-Based Analysis of Adjectives in English Ending in -ic and -ical (Kaunisto, 2007) predstavlja jedan od temeljnih okvira za istraživanje provedeno za potrebe ovoga rada, a koje se usredotočuje na razlikovanje značenja navedenih engleskih pridjeva i njihovu uporabu među neizvornim govornicima. Na samome početku autor navodi primjere parova engleskih pridjeva koji završavaju na -ic i -ical, a koji među sobom ne pokazuju značajnije razlike u značenju, npr. ironic - ironical, pedagogic - pedagogical, satiric - satirical, te one kod kojih se može govoriti o zamjetljivoj značenjskoj razlici, poput classic - classical, economic - economical i historic - historical (Kaunisto, 2007: 4). U ovome ćemo se radu usredotočiti na sljedeće parove koje Kaunisto (2007) detaljno razrađuje: classic - classical, comic - comical, economic - economical, electric - electrical, historic - historical i magic - magical. Osim navedenih parova koje Kaunisto (2007) iscrpno 
analizira, u provedenome istraživanju uključeni su i primjeri rečenica koje uključuju parove za koje Kaunisto (2007: 287) također tvrdi da pokazuju određene razlike $u$ značenju, ali kod kojih je jedan izraz značajnije rjeđi $u$ uporabi od drugog s kojim čini par. Riječ je o sljedećim parovima: politic political, fantastic - fantastical, diabolic - diabolical i optic - optical. U nastavku iznosimo sažet pregled temeljnih razlika među navedenim parovima kako ih obrađuje Kaunisto (2007).

Na samom početku detaljne analize razlika u leksikografskoj obradi i uporabi classic - classical, Kaunisto (2007: 59) potvrđuje da se u različitim opisima temeljna značenjska razlika između ta dva izraza svodi na sljedeće: classic se javlja u modifikacijama koje označavaju nešto što je visoke kvalitete, a classical pri referiranju na umjetnost i autore antičke Grčke i Rima te u izrazu classical music, koji označava vrstu orkestralne glazbe. Nadalje, kod analize temeljnih razlika u uporabi autor navodi sljedeće: pozitivna evaluacija ili vrednovanje (uključujući: 'koji pripada kanonu', 'prvoklasni', 'autoritativni'/'slavan', 'izvanredan') / koji predstavlja vrstu: 'primjeran', 'tipičan', 'arhetipan' / koji se odnosi na antičke kulture / 'koji se pridržava antičkih grčkih ili rimskih ideala'; 'jednostavan, umjeren, elegantan' / tradicionalni sustavi i metode / klasična glazba (Kaunisto, 2007: 69-84).

Kada je riječ o paru comic - comical, Kaunisto (2007: 102-110) o njemu detaljnije raspravlja kroz analizu sljedećih značenjskih aspekata: određivanje nečega 'što pripada komediji' kao književnom žanru / nečega što je zabavno / nečega što je čudno. Pri tome napominje da se značenje 'što pripada komediji' kao književnom žanru danas pripisuje samo izrazu comic.

$\mathrm{Na}$ samom početku poglavlja o paru economic - economical, Kaunisto (2007: 121) navodi osnovnu razliku - economic se odnosi na ekonomiju, dok economical podrazumijeva ekonomičnost i štedljivost. U nastavku autor raspravlja o učestalosti uporabe oba izraza u različitim značenjima, uključujući: 'koji se odnosi na domaćinstvo' / 'koji se odnosi na ekonomiju' / 'nerastrošan; štedljiv, oprezan', 'jeftin' / 'unosan' (Kaunisto, 2007: 128-137).

Za par electric - electrical Kaunisto (2007: 149) utvrđuje kako se razlika $\mathrm{u}$ značenju nije razvila na isti način kao što je to slučaj s parovima classic - classical i historic - historical te kako se nerijetko nalaze primjeri u kojima oba pridjeva imaju isto značenje i modificiraju istu imenicu. O paru electric - electrical Kaunisto (2007: 159-170) raspravlja uzimajući u obzir sljedeća značenja: 'koji ima potencijal za razvoj elektriciteta', 'nabijen elektricitetom' / 'koji se odnosi na električnu struju kao fizičku pojavnost', 'koji proizvodi ili prenosi električnu struju' / 'koji se odnosi na dizajniranje, konstrukciju ili instalaciju električnih izvora, opreme ili drugih aplikacija električne struje' / 'koji senapaja strujom', uporaba u prenesenom značenju i nominalna uporaba izraza. Marsden (1985, citirano u Lipka 1992: 167) smatra da je electrical stariji oblik te da je electric oblik koji se preferira u recentnijim kolokacijama. 
Par pridjeva historic - historical analizira se uzimajući u obzir ponajprije sljedeća značenja: 'koji ima veze s povijesti', 'koji pripada povijesti' / 'koji se temelji na povijesti' / 'koji je postojao u povijesti'; 'koji pripada prošlosti' / 'koji je postojao u povijesti, a u suprotnosti spram fikcijskog ili legendarnog'; ' 'autentičan' / 'slavan ili značajan u povijesti' / 'koji ima dugu povijest' (Kaunisto, 2007: 195-216). Autor navodi da je u suvremenoj uporabi središnje značenje izraza historic 'slavan ili značajan u povijesti' ili ‘koji stvara povijest', dok se historical u navedenom značenju rabi u značajno manjoj mjeri (Kaunisto, 2007: 207). To potvrđuju i raniji izvori. Naime, Leitzke (1989, citirano u Lipka, 1992: 168) jasno razlikuje značenja historic ('slavan u povijesti') i historical ('koji pripada povijesti').

Par pridjeva magic - magical istražuje se uzimajući u obzir ponajprije sljedeća značenja: 'koji se odnosi na vračanje (čarobnjaštvo) ili nadnaravne moći' / 'koji nalikuje čaroliji'; prenesena značenja / 'čaroban, čudesan'; 'izvrstan' (Kaunisto, 2007: 236-248). Autor također navodi i da se u suvremenom engleskom jeziku izraz magical javlja češće u mnogim kolokacijama, ali i da se magic koristi u većoj mjeri kada se govori o obredima ili vračanju, odnosno čarobnjaštvu, primjerice u izrazu magic spell (Kaunisto, 2007: 236-237). S druge strane, Gries (2001: 96) utvrđuje tendenciju prema kojoj se tipične kolokacije koje uključuju magic odnose na određivanje konkretnih objekata, dok se u slučaju kolokacija koje uključuju magical radi o apstraktnoj denotaciji.

Kada je riječ o parovima kod kojih je jedan izraz značajnije rjeđi u uporabi od drugog s kojim čini par, Kaunisto (2007: 288-292) navodi da su izrazi political, fantastic, diabolical i optical mnogo češći u suvremenom engleskom jeziku od izraza politic, fantastical, diabolic i optic. Izraz politic koristi se u značenjima 'razuman', 'mudar' ili 'vješt', dok se political koristi u značenju 'koji se odnosi na vladu ili javne poslove države' i 'koji se odnosi na politiku' (Kaunisto, 2007: 287-288). Dok se i fantastic i fantastical rabe u značenjima 'nestvaran', maštovit' i 'obilježen živom maštom ili fantazijom', izraz fantastic je taj koji se rabi u kontekstu odobravanja ili pohvale, primjerice: It was an absolutely fantastic performance (Kaunisto, 2007: 290). Dok se i diabolic i diabolical rabe u značenju 'koji pripada vragu', 'đavolji' i 'zao', samo se izraz diabolical javlja u značenju 'sramotan' ili 'užasan' (Kaunisto, 2007: 290). Izraz optic javlja se u ograničenom broju kolokacija te se, $\mathrm{u}$ odnosu na optical, $\mathrm{u}$ leksikografskim izvorima u većoj mjeri vezuje uz anatomiju ili medicinu (Kaunisto, 2007: 292). 


\section{RAZLIKE U ZNAČENJU ENGLESKIH PRIDJEVA NA -IC I -ICAL I NJIHOVA UPORABA MEĐU HRVATSKIM GOVORNICIMA}

\subsection{Cilj, istraživačko pitanje i pretpostavka istraživanja}

Cilj provedenoga istraživanja jest opisati uporabu engleskih pridjeva na -ic i -ical među hrvatskim govornicima engleskoga jezika te utvrditi u kojoj mjeri razlikuju njihova značenja. U svrhu ostvarenja navedenoga cilja postavlja se pitanje čimbenika koji se mogu uzeti u obzir pri procjeni mjere u kojoj ispitanici razlikuju značenja engleskih pridjeva na -ic i -ical. Polazimo od pretpostavke da će uspješnost razlikovanja strukturno sličnih i značenjski bliskih engleskih pridjeva ovisiti ponajprije o razlici između njihovih značenja, učestalosti uporabe te o jezičnome okruženju u kojemu se pridjev rabi.

\subsection{Metodologija istraživanja}

U istraživanju kojeje provedenou ožujku i travnju 2019. godine među studentima anglistike sudjelovalo je sveukupno 96 studenata, od čega 54 studenta druge godine preddiplomskoga studija, 33 studenta treće godine preddiplomskoga studija te 9 studenata prve godine diplomskoga studija. Ispitanici su bili informirani o cilju istraživanja i svemu što je relevantno za njihovo sudjelovanje $\mathrm{u}$ istraživanju te su dobrovoljno pristali sudjelovati $\mathrm{u}$ istraživanju. Sveučilišna razina poznavanja engleskoga jezika među neizvornim govornicima, na kojoj studenti anglistike usvajaju i rabe složenije jezične izraze i strukture, uključujući i kolokacije, uzima se kao primjerena za analizu razumijevanja razlika u značenju i uporabi obrađenih parova engleskih pridjeva.

Unutar rečenice određenoga jezika pridjevi mogu zauzimati različite pozicije, a o okruženjima u sklopu kojih se u engleskome jeziku mogu javiti pridjevi svjedoče jezikoslovni izvori (usp. Matthews, 2014; Tucker, 1998: 53-54). Jedno od takvih okruženja u engleskome jeziku odnosi se na ono u kojemu pridjevi unutar imenskih skupina prethode imenici koju modificiraju. U tome slučaju govorimo o pridjevno-imeničkim kolokacijama, odnosno pridjevima kao predmodifikatorima ${ }^{7} \mathrm{u}$ imenskim skupinama. Većina rečenica koje se koriste $u$ istraživanju, a koje sadrže navedene pridjeve uključuje takvu pojavnost pridjeva. Međutim, s obzirom na to da je osnovni cilj ovoga rada utvrditi razlikovanje značenja pridjeva na -ic i -ical te kontekste njihove uporabe u pojedinim značenjima, primjeri neće biti ograničeni samo na navedeno okruženje u kojem se ti pridjevi javljaju. Zbog toga se $\mathrm{u}$ istraživanju ne navode izolirane imenske skupine s pridjevima kao predmodifikatorima, već cijele rečenice u kojima se javljaju pojedini pridjevi na -ic i-ical u određenom značenju i položaju u rečenici.

\footnotetext{
${ }^{7}$ Izraz 'predmodifikator' ovdje se rabi u značenju u kojemu se u engleskome jeziku rabi izraz 'premodifier'.
} 
Studentima je u obliku testa ponuđeno 56 rečenica koje sadrže analizirane pridjeve. Korištene rečenice temelje se na primjerima koji su u mrežnom izdanju Oxfordova rječnika engleskoga jezika navedeni kao primjeri uporabe pridjeva u pojedinom značenju, pri čemu se osobito vodilo računa da se, gdjegod je bilo moguće, zadrži kolokacija koja je u rječniku navedena za to značenje. Od studenata se tražilo da podcrtaju jedan od dva ponuđena izraza za koji smatraju da je ispravan u navedenim rečenicama te da ga prevedu na hrvatski jezik. ${ }^{8} \mathrm{U}$ testu su rečenice poredane nasumičnim redoslijedom, a u nastavku se zajedno s rezultatima navode prema redoslijedu koji je naveden $\mathrm{u}$ prethodnome dijelu rada gdje se daje osvrt na analizu razlika među parovima pridjeva kako ih navodi Kaunisto (2007). ${ }^{9}$

\subsection{Analiza rezultata istraživanja}

$\mathrm{U}$ analizi rezultata istraživanja koristimo se mrežnim izdanjem Oxfordova rječnika engleskoga jezika ${ }^{10}$ kako bismo imali uvid u najrecentniju leksikografsku obradu izraza na koje se usredotočujemo. ${ }^{11}$ Samo u jednom slučaju u navedenom izvoru nije utvrđen unos za oba izraza u paru pa se konzultiraju i dodatni leksikografski izvori. Kako bi se utvrdila frekvencija kolokacija koje sadrže obrađene pridjeve i koje se javljaju u korištenim rečenicama, konzultiramo i Britanski nacionalni korpus $(\mathrm{BNC})^{12}$ te Korpus suvremenog američkog engleskog jezika (COCA) ${ }^{13}$.

Analiza rezultata istraživanja predstavlja se za svaki par pridjeva pojedinačno. Opisnome dijelu analize za svaki par pridjeva slijedi tablica koja sadrži obradu prikupljenih podataka. U tablicama se prvo iznose sva značenja pridjeva kako su navedena $\mathrm{u}$ OED- $\mathrm{u}^{14}$ zajedno s rečenicama koje su korištene $u$ istraživanju, odnosno $u$ primijenjenom testu, i koje sadrže

\footnotetext{
${ }^{8}$ Dio istraživanja koji se odnosi na prijevode engleskih izraza na hrvatski jezik ne izlaže se u ovome radu zbog ograničenja prostora.

${ }^{9}$ S obzirom na to da se u tablicama koje slijede navode sve rečenice korištene u istraživanju, ali drugačijim redoslijedom, u prilogu rada ne uključujemo popis korištenih rečenica, a zbog uštede prostora.

${ }^{10}$ https://en.oxforddictionaries.com/english (15. veljače 2019.). U nastavku ćemo se na ovaj izvor referirati koristeći se kraticom OED.

${ }^{11} \mathrm{U}$ detaljnom povijesnom pregledu načina na koji su analizirani pridjevi obrađeni u različitim rječnicima Kaunisto (2007) se koristi nizom leksikografskih izvora, a navodi i unose iz The Oxford English Dictionary za navedene pridjeve, pri čemu se koristi 2. izdanjem rječnika iz 1992. U ovome se radu koristi mrežno izdanje Oxfordovog rječnika engleskoga jezika, koji je dio Oxford Global Languages (OGL) programa. Navedeno izdanje uključuje suvremenu leksikografsku obradu koja može pokazivati određena odstupanja od obrade u drugim, tiskanim izdanjima Oxfordova rječnika engleskoga jezika. S obzirom na to da osnovni cilj ovoga rada ne uključuje dijakronijsku perspektivu, već se odnosi na utvrđivanje trenutačnog poznavanja razlika u značenju i uporabi navedenih parova engleskih pridjeva na -ic i -ical među hrvatskim neizvornim govornicima engleskoga jezika, pretpostavljamo da se oni u velikoj mjeri koriste upravo mrežnim izdanjem Oxfordova rječnika engleskoga jezika.

12 British National Corpus. https://www.english-corpora.org/bnc/ (17. rujna 2019.). U nastavku ćemo se na ovaj izvor referirati koristeći se kraticom BNC.

${ }^{13}$ Corpus of Contemporary American English. https://www.english-corpora.org/coca/ (17. rujna 2019.). U nastavku ćemo se na ovaj izvor referirati koristeći se kraticom COCA.

${ }^{14}$ Značenja unesena u OED s engleskog na hrvatski prevela je autorica ovoga rada.
} 
pridjev koji se $\mathrm{u}$ tom kontekstu navodi u OED-u. ${ }^{15} \mathrm{U}$ tablicama se potom navode odgovori ispitanika za svaku rečenicu izraženi u postotcima. Ti se podaci odnose na postotak ispitanika koji su kod pojedine rečenice birali -ic pridjev te postotak onih koji su birali -ical pridjev. Osim pojedinačnih postotaka za svaku rečenicu, tablica prikazuje i omjer sveukupnih postotaka za sva značenja pojedinog pridjeva u paru kako je navedeno u OED-u te omjer sveukupnih postotaka za svaki od dva pridjeva. Pri opisu analiziranih podataka navode se rezultati hi-kvadrat $\left(\chi^{2}\right)$ testa, koji je proveden kako bi se utvrdilo jesu li razlike statistički značajne.

Kada je riječ o paru classic - classical (rezultati obrade prikupljenih podataka za ovaj par prikazani su u tablici 1.), razlika između sveukupne uporabe jednog i drugog pridjeva nije statistički značajna $\left(\chi^{2}=0,021\right.$; $p=, 88523)^{16}$. Međutim, razlike u distribuciji odgovora za sva značenja oba pridjeva statistički su značajne, pri čemu ispitanici u značajno većoj mjeri biraju izraz classic kod rečenica u kojima se taj pridjev javlja $\left(\chi^{2}=117,556\right.$; $p<, 00001)$ te izraz classical kod rečenica koje sadrže taj pridjev $\left(\chi^{2}=73,633\right.$; $p<, 00001)$. Navedeni rezultati ukazuju na to da ispitanici razlikuju značenja koja su u OED-u navedena za classic od onih koja su navedena za classical. To je u skladu i s razlikovanjem značenja koje navodi Kaunisto (2007: 59), pri čemu se classic javlja u modifikacijama koje označavaju nešto što je visoke kvalitete, a classical pri referiranju na umjetnost i autore antičke Grčke i Rima te u izrazu classical music. U većini rečenica pridjevi se javljaju u kolokacijama s kojima su se ispitanici vjerojatno češće susretali pa se visoki postotci točnih odgovora u tim slučajevima mogu pripisati ne samo razlikovanju značenja, već i većoj izloženosti navedenim kolokacijama. To potvrđuju i frekvencije kolokacija s oba pridjeva u BNC-u i COCA-i. Naime, u navedenim je korpusima veća frekvencija izraza classic car (BNC (15); COCA (93) $)^{17} \mathrm{u}$ usporedbi s classical car (BNC (0); COCA (2)), classic symptoms (BNC (14); COCA (78)) u usporedbi s classical symptoms (BNC (0); COCA (3)), classical mythology (BNC (27); COCA (35)) u usporedbi s classic mythology (BNC (0); COCA (2)), classical architecture (BNC (16); COCA (47)) u usporedbi s classic architecture (BNC (1); COCA (11)) te classical ballet (BNC (29); COCA (118)) u usporedbi s classic ballet (BNC (1); COCA (9)). Izraz classic Hollywood period ne javlja se ni u jednom korpusu, dok se classical Hollywood period javlja jednom u COCA-i, a u BNC-u ne. Izuzetak većinskoj uporabi izraza koji se javlja u OED-u čine odgovori ispitanika za značenje pod 2.2 za classical koje je, za razliku od prethodnih značenja, vrlo usko i odnosi se na područje fizike, a,

\footnotetext{
${ }_{15}$ Rečenice koje su korištene $\mathrm{u}$ istraživanju u tablici su navedene u kurzivu. U primijenjenom testu je prvi navedeni izraz u svakoj rečenici morfološki jednostavniji.

${ }_{16}$ Rezultati su statistički značajni na $p<, 05$ razini.

${ }^{17}$ Brojke u zagradama odnose se na broj, odnosno frekvenciju pojedine kolokacije koja se javlja u određenom korpusu.
} 
u usporedbi s ostalim kolokacijama, u ovome se slučaju pridjev ne javlja u kolokaciji koja je često u uporabi. Naime, izrazi classic field theory i classical field theory uopće se ne javljaju u konzultiranim korpusima. Također, veća frekvencija classic design u usporedbi s classical design (40:12) uočena je u COCA-i, ali ne i u BNC-u (3:12).

Tablica 1. Distribucija odgovora ispitanika za par "classic-classical"

\begin{tabular}{|c|c|c|c|}
\hline Pridjev & Značenje pridjeva i rečenica & $-i c$ & $-i c a l$ \\
\hline \multirow[t]{3}{*}{ classic } & $\begin{array}{l}1 \text { koji je kroz određeni vremenski period procijenjen } \\
\text { vrhunske kvalitete i izvanredan unutar svoje vrste: } \\
\text { After his father passed away, John inhereted his rare classic car. }\end{array}$ & $87,50 \%$ & $12,50 \%$ \\
\hline & $\begin{array}{l}1.1 \text { (odjeća ili dizajn) jednostavnog, elegantnog stila koji } \\
\text { nije u velikoj mjeri podložan modnim promjenama: } \\
\text { Fashion designers frequently take a classic design and modify it } \\
\text { so that it looks more modern. }\end{array}$ & $83,33 \%$ & $16,67 \%$ \\
\hline & $\begin{array}{l}2 \text { vrlo tipičan za svoju vrstu: } \\
\text { What are the classic symptoms of depression? }\end{array}$ & $75,00 \%$ & $25,00 \%$ \\
\hline Sveukupno classic & & $81,94 \%$ & $18,06 \%$ \\
\hline \multirow[t]{5}{*}{ classical } & $\begin{array}{l}1 \text { koji se odnosi na antičku grčku ili latinsku književnost, } \\
\text { umjetnost ili kulturu: } \\
\text { Steven started learning Greek and Latin, and he also enrolled in } \\
\text { courses in classical mythology and Greek literature. }\end{array}$ & $34,38 \%$ & $65,63 \%$ \\
\hline & $\begin{array}{l}1.1 \text { (umjetnost ili arhitektura) pod utjecajem antičkih } \\
\text { grčkih ili rimskih oblika ili principa: } \\
\text { Many architects have analyzed the building and have noticed } \\
\text { that it has many characteristics of classical architecture. }\end{array}$ & $15,63 \%$ & $84,38 \%$ \\
\hline & $\begin{array}{l}2 \text { koji predstavlja primjeran standard unutar } \\
\text { tradicionalnog i davno utemeljenog oblika ili stila: } \\
\text { Leyla quit classical ballet because it was too difficult. }\end{array}$ & $7,29 \%$ & $92,71 \%$ \\
\hline & $\begin{array}{l}2.1 \text { koji se odnosi na prvo značajno razdoblje područja } \\
\text { istraživanja: } \\
\text { That film was made in the classical Hollywood period. }\end{array}$ & $35,42 \%$ & $64,58 \%$ \\
\hline & $\begin{array}{l}\text { 2.2 Fizika koji se odnosi ili temelji na pojmovima i } \\
\text { teorijama koje su prethodile teorijama relativnosti i } \\
\text { kvantne mehanike; njutnovski: } \\
\text { Newton's work marked the beginning of classical field theory. }\end{array}$ & $59,38 \%$ & $40,63 \%$ \\
\hline $\begin{array}{l}\text { Sveukupno } \\
\text { classical }\end{array}$ & & $30,42 \%$ & $69,58 \%$ \\
\hline $\begin{array}{l}\text { Sveukupno classic } \\
\text { i classical }\end{array}$ & & $49,74 \%$ & $50,26 \%$ \\
\hline
\end{tabular}

U slučaju para comic - comical (v. tablicu 2.), ispitanici se u većoj mjeri koriste pridjevom comic $\left(\chi^{2}=8,681 ; p=, 00322\right)$. Razlike u distribuciji odgovora za sva značenja oba pridjeva također su značajne, pri čemu ispitanici $u$ značajno većoj mjeri biraju izraz comic kod rečenica u kojima se taj pridjev javlja $\left(\chi^{2}=52,083 ; p<, 00001\right)$ te izraz comical kod rečenice koja sadrži taj pridjev ( $\left.\chi^{2}=26,042 ; p<, 00001\right)$. Navedeni rezultati ukazuju na to da ispitanici razlikuju značenja koja su u OED-u navedena za comic od onog koji je 
naveden za comical. To je u skladu i s razlikovanjem značenja koje navodi Kaunisto (2007: 103), koji navodi da se značenje 'što pripada komediji' kao književnom žanru danas pripisuje samo izrazu comic. Odabir pridjeva koji je naveden u OED-u među ispitanicima je većinski ispravan čak i u slučaju kada su značenja za comic i comical jako bliska s obzirom na kolokacije u kojima se javljaju - značenje pod 1 za comic i značenje za comical (comic effectcomical manner). Međutim, značenje cijele rečenice u kojoj se javlja comic effect ukazuje na poveznicu s komedijom kao književnim žanrom, što nije slučaj $\mathrm{s}$ rečenicom u kojoj se javlja comical manner. Ovdje treba napomenuti da je izraz comic effect (40) češći od comical effect (4) u COCA-i, a comical effect se ni ne javlja u BNC-u, za razliku od comic effect (5). Izraz comic actor u različitom se broju javlja i u BNC-u (8) i u COCA-i (66), dok se izraz comical actor uopće ne javlja u navedenim korpusima. U COCA-i su izrazi comic manner (1) i comical manner (1) jednako zastupljeni, dok se u BNC-u comical manner ne javlja, za razliku od comic manner (3).

Tablica 2. Distribucija odgovora ispitanika za par "comic-comical“

\begin{tabular}{|c|l|c|c|}
\hline Pridjev & \multicolumn{1}{|c|}{ Značenje pridjeva i rečenica } & $-i c$ & $-i c a l$ \\
\hline comic & $\begin{array}{l}\text { 1 koji uzrokuje ili je namijenjen da uzrokuje smijeh: } \\
\text { The actress was exaggerating in order to produce a comic effect. }\end{array}$ & $66,67 \%$ & $33,33 \%$ \\
\cline { 2 - 4 } & $\begin{array}{l}\text { 1.1 koji se odnosi na ili je u stilu komedije: } \\
\text { His acting repertoire is not very diverse; he is primarily a comic } \\
\text { actor. }\end{array}$ & $85,42 \%$ & $14,58 \%$ \\
\hline Sveukupno comic & $\begin{array}{c}\text { zabavan, osobito na smiješan ili apsurdan način: } \\
\text { She moved clumsily around the room in a comical manner to } \\
\text { amuse us. }\end{array}$ & $23,96 \%$ & $76,04 \%$ \\
\hline comical & & $23,96 \%$ & 76,04 \\
\hline $\begin{array}{c}\text { Sveukupno } \\
\text { comical }\end{array}$ & $\begin{array}{c}\text { Sveukupno comic } \\
\text { i comical }\end{array}$ & $58,68 \%$ & $41,32 \%$ \\
\hline
\end{tabular}

Kada je riječ o paru economic - economical (v. tablicu 3.), ispitanici se sveukupno u značajno većoj mjeri koriste pridjevom economical $\left(\chi^{2}=35,880\right.$; $p<, 00001)$. Kod značenja pridjeva economic kako je navedeno u OED-u, ispitanici u nešto većoj mjeri biraju pridjev economical, ali ta razlika nije statistički značajna $\left(\chi^{2}=0,510 ; p=, 47496\right)$. Značajne su razlike u odgovorima za navedena značenja pridjeva economical, kod kojih ispitanici većinski odabiru upravo economical $\left(\chi^{2}=60,167 ; p<, 00001\right)$. Navedeni rezultati mogli bi ukazivati na to da ispitanici ne razlikuju u potpunosti značenja koja su u OED-u navedena za economic od onih koja su navedena za economical. Međutim, ovdje možemo primijetiti i to da ispitanici kod rečenica 2 i 2.1 za economic većinski biraju economical, a s obzirom na to da su značenja u tom kontekstu bliska značenju economical pod 1., što upućuje na to da ispitanici ipak razlikuju značenje usko vezano za ekonomiju od onog koje se odnosi 
na oblike štedljivosti (v. Kaunisto, 2007: 121). Također, većina ispitanika rabi ispravan izraz $\mathrm{u}$ fiksnoj frazi be economical with the truth. I frekvencija kolokacija upućuje na razlike u uporabi obrađenih pridjeva. Naime, u konzultiranim korpusima kolokacije economic policy (BNC (636); COCA (1769)) i economic history (BNC (200); COCA (282)) pokazuju relativno visoku frekvenciju, dok se izrazi economical policy i economical history u njima uopće ne javljaju. Također, iako se pridjevi economic i economical u ponuđenoj rečenici za značenje economical pod 1 nisu javili u obliku kolokacije s imenicom car, ovdje se možemo osvrnuti i na frekvencije tih kolokacija. U konzultiranim korpusima kolokacija economical car javlja se u oba korpusa (BNC (2); COCA (3)), dok se economic car javlja samo u COCA-i (1).

Tablica 3. Distribucija odgovora ispitanika za par "economic-economical"

\begin{tabular}{|c|c|c|c|}
\hline Pridjev & Značenje pridjeva i rečenica & $-i c$ & $-i c a l$ \\
\hline \multirow[t]{4}{*}{ economic } & $\begin{array}{l}1 \text { koji se odnosi na ekonomiju: } \\
\text { The government needs to develop a more effecient economic } \\
\text { policy. }\end{array}$ & $80,21 \%$ & $19,79 \%$ \\
\hline & $\begin{array}{l}1.1 \text { (predmet) koji se razmatra u odnosu na trgovinu, } \\
\text { industriju i stvaranje bogatstva: } \\
\text { The book is very valuable as it provides an overview of British } \\
\text { economic history. }\end{array}$ & $73,96 \%$ & $26,04 \%$ \\
\hline & $\begin{array}{l}2 \text { profitabilno opravdan: } \\
\text { Small stores frequently form partnerships in order to remain } \\
\text { economic. }\end{array}$ & $8,33 \%$ & $91,67 \%$ \\
\hline & $\begin{array}{l}2.1 \text { koji zahtijeva manje sredstava ili koji košta manje: } \\
\text { The land is very expensive in this area, so it is more economic to } \\
\text { build apartments there rather than turn it into a park. }\end{array}$ & $30,21 \%$ & $69,79 \%$ \\
\hline $\begin{array}{c}\text { Sveukupno } \\
\text { economic }\end{array}$ & & $48,18 \%$ & $51,82 \%$ \\
\hline \multirow[t]{4}{*}{ economical } & $\begin{array}{l}1 \text { koji pruža dobru vrijednost ili povrat u odnosu na } \\
\text { utrošen novac, vrijeme ili napor: } \\
\text { The car is not only small and economical. It is also quick. }\end{array}$ & $27,08 \%$ & $72,92 \%$ \\
\hline & $\begin{array}{l}1.1 \text { (osoba ili životni stil) oprezan kako ne bi uzaludno } \\
\text { trošio novac ili sredstva: } \\
\text { My parents were very economical, so they managed to save some } \\
\text { money for our education. }\end{array}$ & $25,00 \%$ & $75,00 \%$ \\
\hline & $\begin{array}{l}1.2 \text { koji od nečega ne koristi više nego što je potrebno: } \\
\text { The company is known for producing motors that are very } \\
\text { economical with fuel. }\end{array}$ & $40,63 \%$ & $59,38 \%$ \\
\hline & $\begin{array}{l}\text { be economical with the } \text { truth }^{18} \text { - lagati ili namjerno uskratiti } \\
\text { informaciju: } \\
\text { Most politicians are economical with the truth. }\end{array}$ & $28,13 \%$ & $71,88 \%$ \\
\hline $\begin{array}{l}\text { Sveukupno } \\
\text { economical }\end{array}$ & & $30,21 \%$ & $69,79 \%$ \\
\hline $\begin{array}{l}\text { Sveukupno } \\
\text { economic i } \\
\text { economical }\end{array}$ & & $39,19 \%$ & $60,81 \%$ \\
\hline
\end{tabular}

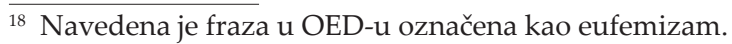


U slučaju para electric - electrical (v. tablicu 4.), ispitanici se sveukupno u značajno većoj mjeri koriste pridjevom electric $\left(\chi^{2}=177,633 ; p<, 00001\right)$. Razlike u distribuciji odgovora za sva značenja oba pridjeva također su značajne, pri čemu ispitanici u značajno većoj mjeri biraju izraz electric kod rečenica u kojima se taj pridjev javlja $\left(\chi^{2}=130,681 ; p<, 00001\right)$, ali i kod rečenica koje sadrže pridjev electrical $\left(\chi^{2}=50,021 ; p<, 00001\right)$. Navedeni rezultati ukazuju na to da ispitanici ne razlikuju u potpunosti značenja koja su u OED-u navedena za electric od onih koja su navedena za electrical. Međutim, većina značenja unesena za oba pridjeva u OED-u ne ukazuju na značajniju razliku među njima (v. Kaunisto, 2007: 149). Odgovori ispitanika za electric pod 1 i 1.1 ukazuju na učestalost izloženosti određenim kolokacijama, poput electric cooker i electric bass guitar. Učestalost navedenih kolokacija, a u usporedbi s electrical cooker i electrical bass guitar, potvrđuju BNC i COCA. Naime, u navedenim se korpusima, za razliku od electric cooker (BNC (28); COCA (4)) i electric bass guitar (BNC (2); COCA (4)), izrazi electrical cooker i electrical bass guitar ni ne javljaju. $S$ druge strane, odgovori ispitanika nisu u skladu s frekvencijama izraza koji se u konzultiranim korpusima javljaju u rečenicama za značenje electrical. Naime, u tim je slučajevima riječ o većoj frekvenciji izraza electrical appliances (BNC (59); COCA (84)) u usporedbi s electric appliances (BNC (3); COCA (28)) te izraza electrical shop (BNC (10); COCA (5)) u usporedbi s electric shop (BNC (5); COCA (2)). Ovdje valja opet napomenuti da Marsden (1985, kako je navedeno u Lipka, 1992: 167) smatra da je electric oblik koji se preferira u recentnijim kolokacijama. S druge strane, većina ispitanika ispravno se koristi izrazom electric kada se koristi u metaforičkome značenju, kako je navedeno pod 2. Iako se pridjevi electric i electrical $\mathrm{u}$ ponuđenoj rečenici nisu javili u obliku kolokacije $\mathrm{s}$ imenicom atmosphere, ovdje se osvrćemo i na frekvencije kolokacija s tom imenicom. U konzultiranim se korpusima kolokacija electrical atmosphere uopće ne javlja, što nije slučaj s electric atmosphere (BNC (5); COCA (22)).

Tablica 4. Distribucija odgovora ispitanika za par "electric-electrical"

\begin{tabular}{|c|l|c|c|}
\hline Pridjev & \multicolumn{1}{|c|}{ Značenje pridjeva i rečenica } & -ic & -ical \\
\hline electric & $\begin{array}{l}\text { 1 koji je vezan za, koji radi na, koji je napunjen sa ili koji } \\
\text { proizvodi struju: } \\
\text { Her kitchen is equipped with an electric cooker. }\end{array}$ & $91,67 \%$ & $8,33 \%$ \\
\cline { 2 - 5 } & $\begin{array}{l}\text { 1.1 (glazbeni instrument) koji je pojačan kroz zvučnik: } \\
\text { My boyfriend bought me an electric bass guitar for my birthday. }\end{array}$ & $88,54 \%$ & $11,46 \%$ \\
\cline { 2 - 5 } & $\begin{array}{l}\text { 2 koji ima ili stvara iznenadan osjećaj ushićenog } \\
\text { uzbuđenja: } \\
\text { The atmosphere was electric, and everyone who came to the } \\
\text { concert could feel it. }\end{array}$ & $70,83 \%$ & $29,17 \%$ \\
\hline $\begin{array}{c}\text { Sveukupno } \\
\text { electric }\end{array}$ & & $83,68 \%$ & $16,32 \%$ \\
\hline
\end{tabular}




\begin{tabular}{|c|l|c|c|}
\hline electrical & $\begin{array}{l}\text { 1 koji se tiče, koji djeluje putem ili koji proizvodi struju: } \\
\text { This store does not sell electrical appliances. }\end{array}$ & $65,63 \%$ & $34,38 \%$ \\
\cline { 2 - 4 } & $\begin{array}{l}\text { 1.1 (tvrtka ili trgovina) koja proizvodi ili prodaje električne } \\
\text { uređaje: } \\
\text { I had to replace the light bulb in my room, so I went to the } \\
\text { electrical shop to buy one. }\end{array}$ & $85,42 \%$ & $14,58 \%$ \\
\hline $\begin{array}{c}\text { Sveukupno } \\
\text { electrical }\end{array}$ & & $75,52 \%$ & $24,48 \%$ \\
\hline $\begin{array}{c}\text { Sveukupno } \\
\text { electric i electrical }\end{array}$ & & $80,42 \%$ & $19,58 \%$ \\
\hline
\end{tabular}

Kod para historic - historical (v. tablicu 5.) ispitanici sveukupno u značajno većoj mjeri biraju pridjev historical $\left(\chi^{2}=178,149 ; p<, 00001\right)$. Također, statistička značajnost utvrđena je u korist izraza historical i kod analize primjera kojima se predstavljaju značenja pridjeva historic $\left(\chi^{2}=72,000 ; p<, 00001\right)$ te kod onih kojima se predstavljaju značenja pridjeva historical $\left(\chi^{2}=106,260 ; p<, 00001\right)$. Navedeni rezultati ukazuju na to da ispitanici ne razlikuju značenja koja su $u$ OED-u navedena za historic od onih koja su navedena za historical, odnosno da ne razlikuju određenje nečega što pripada prošlosti od određenja nečega što je (potencijalno) slavno ili bitno u prošlosti (v. Kaunisto, 2007: 207; Leitzke, 1989 u Lipka, 1992: 168). Kada je riječ o kolokacijama koje se javljaju u korištenim rečenicama, oba konzultirana korpusa u svim slučajevima osim dva potvrđuju veću frekvenciju onoga pridjeva koji se u rečenicama i javlja u kolokaciji s određenom imenicom. Riječ je o većoj frekvenciji izraza historic sites (BNC (36); COCA (390)) u usporedbi s historical sites (BNC (16); COCA (145)), historic houses (BNC (50); COCA (102)) u usporedbi s historical houses (BNC (2); COCA (3)), historical evidence (BNC (84); COCA (326)) u usporedbi s historic evidence (BNC (1); COCA (5)), historical figures (BNC (20); COCA (315)) u usporedbi s historic figures (BNC (2); COCA (32)) te historical analysis (BNC (43); COCA (211)) u usporedbi s historic analysis (BNC (0); COCA (3)). U BNC-u se i historic films i historical films javljaju samo jednom, dok je $\mathrm{u}$ COCA-i ipak veća frekvencija izraza historical films (15:2). Izraz historic tenses ne javlja se ni u jednom korpusu, ali je u COCA-i historical tenses zabilježen jednom. 
ŠKIFIĆ: RAZlikovANJE ZNAČENJA I UPORABA ENGLESKIH PRIDJEVA... (STR. 31-55)

Tablica 5. Distribucija odgovora ispitanika za par "historic-historical"

\begin{tabular}{|c|c|c|c|}
\hline Pridjev & Značenje pridjeva i rečenica & $-i c$ & $-i c a l$ \\
\hline \multirow[t]{3}{*}{ historic } & $\begin{array}{l}1 \text { slavan ili bitan u povijesti, ili potencijalno slavan ili bitan } \\
\text { u povijesti: } \\
\text { Many tourists visit Egypt, primarily due to its numerous } \\
\text { historic sites. }\end{array}$ & $12,50 \%$ & $87,50 \%$ \\
\hline & $\begin{array}{l}1.1 \text { arhaično koji pripada ili se odnosi na povijest; prošli: } \\
\text { In the book the author also discusses the destruction of historic } \\
\text { houses and homes. }\end{array}$ & $32,29 \%$ & $67,71 \%$ \\
\hline & $\begin{array}{l}2 \text { gramatika (glagolsko vrijeme) koje se koristi u } \\
\text { prepričavanju prošlih događaja, osobito latinski i grčki } \\
\text { imperfekt i pluskvamperfekt: } \\
\text { The grammar discusses at lenght the historic tenses of the } \\
\text { language. }\end{array}$ & $30,21 \%$ & $69,79 \%$ \\
\hline $\begin{array}{c}\text { Sveukupno } \\
\text { historic }\end{array}$ & & $25,00 \%$ & $75,00 \%$ \\
\hline \multirow[t]{4}{*}{ historical } & $\begin{array}{l}1 \text { koji pripada ili se odnosi na povijest ili prošle događaje: } \\
\text { There is no historical evidence to support such claims. }\end{array}$ & $27,08 \%$ & $72,92 \%$ \\
\hline & $\begin{array}{l}1.1 \text { koji pripada prošlosti: } \\
\text { The course also provides an insight into the lives of the area's } \\
\text { leading historical figures. }\end{array}$ & $20,83 \%$ & $79,17 \%$ \\
\hline & $\begin{array}{l}1.2 \text { (osobito roman ili film) koji je smješten u prošlosti: } \\
\text { I prefer historical films because they provide an insight into past } \\
\text { ways of life. }\end{array}$ & $17,71 \%$ & $82,29 \%$ \\
\hline & $\begin{array}{l}1.3 \text { (istraživanje predmeta) koji se temelji na analizi } \\
\text { njegova razvoja kroz određeni period: } \\
\text { If you want to understand patterns of social change, you should } \\
\text { take into consideration the historical analysis of classes. }\end{array}$ & $29,17 \%$ & $70,83 \%$ \\
\hline $\begin{array}{l}\text { Sveukupno } \\
\text { historical }\end{array}$ & & $23,70 \%$ & $76,30 \%$ \\
\hline $\begin{array}{c}\text { Sveukupno } \\
\text { historic i historical }\end{array}$ & & $24,26 \%$ & $75,74 \%$ \\
\hline
\end{tabular}

Kada je riječ o paru magic - magical (v. tablicu 6.), ispitanici sveukupno u značajno većoj mjeri biraju pridjev magical $\left(\chi^{2}=21,675 ; p<, 00001\right)$. Također, ispitanici u značajno većoj mjeri biraju izraz magic kod rečenica u kojima se taj pridjev javlja $\left(\chi^{2}=10,125 ; p=, 00146\right)$ te izraz magical kod rečenica koje sadrže taj pridjev $\left(\chi^{2}=126,750 ; p<, 00001\right)$. Navedeni rezultati ukazuju na to da ispitanici razlikuju značenja koja su u OED-u navedena za magic od onih koja su navedena za magical. S obzirom na kolokacije koje se javljaju $\mathrm{u}$ korištenim rečenicama, oba konzultirana korpusa u svim slučajevima potvrđuju veću frekvenciju onoga pridjeva koji se u rečenicama i javlja u kolokaciji s određenom imenicom. Radi se o većoj frekvenciji izraza magic spells (BNC (14); COCA (36)) u usporedbi s magical spells (BNC (4); COCA (11)), magic ingredient (BNC (9); COCA (38)) u usporedbi s magical ingredient (BNC (2); COCA (5)) i magical powers (BNC (24); COCA (138)) u usporedbi s magic powers (BNC (8); COCA (49)). Iako su značenja za magic i magical pod 
2 vrlo bliska, većina ispitanika povezuje pridjev magical s tim značenjem. Povezanost navedenih značenja evidentna je i u bliskosti značenja cijele kolokacije, odnosno kombinacije pridjeva i imenice $s$ kojima navedeni pridjevi u tim rečenicama ulaze $\mathrm{u}$ kolokaciju - magic moments i magical evening. Nešto veću učestalost navedenih kolokacija, a u usporedbi s magical moments i magic evening, potvrđuju BNC i COCA. Naime u navedenim se korpusima izraz magic moments (BNC (7); COCA (52)) javlja češće nego izraz magical moments (BNC (3); COCA (31)), dok se, za razliku od magical evening (BNC (3); COCA (15)), izraz magic evening u njima ni ne javlja.

Tablica 6. Distribucija odgovora ispitanika za par "magic-magical“

\begin{tabular}{|c|c|c|c|}
\hline Pridjev & Značenje pridjeva i rečenica & $-i c$ & -ical \\
\hline \multirow[t]{3}{*}{ magic } & $\begin{array}{l}1 \text { koji ima ili prividno ima nadnaravne moći: } \\
\text { She wanted to learn the art of working wonders by magic spells. }\end{array}$ & $94,79 \%$ & $5,21 \%$ \\
\hline & $\begin{array}{l}1.1 \text { [atributivno] vrlo učinkovit u ostvarivanju željenih } \\
\text { rezultata: } \\
\text { Susan refused to reveal the magic ingredient that she used in her } \\
\text { holistic medicine. }\end{array}$ & $69,79 \%$ & $30,21 \%$ \\
\hline & $\begin{array}{l}2 \text { britanski engleski; neformalno izvanredan; uzbuđujući: } \\
\text { Life is not easy, so enjoy the few magic moments that you get. }\end{array}$ & $13,54 \%$ & $86,46 \%$ \\
\hline Sveukupno magic & & $59,38 \%$ & $40,63 \%$ \\
\hline \multirow[t]{2}{*}{ magical } & $\begin{array}{l}1 \text { koji se odnosi na, koji koristi ili nalikuje magiji: } \\
\text { Her kind words always had magical healing powers. }\end{array}$ & $16,67 \%$ & $83,33 \%$ \\
\hline & $\begin{array}{l}2 \text { prekrasan ili ugodan na nesvakidašnji način: } \\
\text { It was a magical evening for all of us. }\end{array}$ & $2,08 \%$ & $97,92 \%$ \\
\hline $\begin{array}{l}\text { Sveukupno } \\
\text { magical }\end{array}$ & & $9,38 \%$ & $90,63 \%$ \\
\hline $\begin{array}{l}\text { Sveukupno magic } \\
\text { i magical }\end{array}$ & & $39,38 \%$ & $60,62 \%$ \\
\hline
\end{tabular}

U slučaju para politic - political (v. tablicu 7.) ispitanici sveukupno u značajno većoj mjeri biraju pridjev political $\left(\chi^{2}=414,857 ; p<, 00001\right)$. Također, statistička značajnost utvrđena je u korist izraza political i kod analize svih primjera kojima se predstavljaju značenja pridjeva politic $\left(\chi^{2}=111,021\right.$; $p<, 00001)$ te kod onih kojima se predstavljaju značenja pridjeva political $\left(\chi^{2}=304,008 ; p<, 00001\right)$. Navedeni rezultati ukazuju na to da ispitanici ne razlikuju značenja koja su u OED-u navedena za politic od onih koja su navedena za political. Naime, na temelju rezultata možemo zaključiti da većina ne zna razliku između značenja pridjeva politic ('razborit, razuman, mudar') i political ('koji se odnosi na vladu i javne poslove države'), što se opet može dovesti u vezu sa značajnije rjeđom uporabom izraza politic, odnosno s manjom izloženosti tome izrazu (v. Kaunisto 2007: 287-288). To potvrđuju i frekvencije pojedinih kolokacija u obrađenim korpusima. Naime, politic( $k$ ) ruler se u njima ne javlja ni u jednom, a political ruler samo jednom u COCA-i. Izrazi politic stability, politic reasons, politic life, politic crimes i politic agenda $\mathrm{u}$ 
korpusima se uopće ne javljaju, za razliku od political stability (BNC (112); COCA (624)), political reasons (BNC (137); COCA (870)), political life (BNC (325); COCA (1660)), political crimes (BNC (13); COCA (33)) i political agenda (BNC (105); COCA (1017)).

Tablica 7. Distribucija odgovora ispitanika za par "politic-political”

\begin{tabular}{|c|c|c|c|}
\hline Pridjev & Značenje pridjeva i rečenica & $-i c$ & $-i c a l$ \\
\hline \multirow[t]{2}{*}{ politic } & $\begin{array}{l}1 \text { (postupak) koji se čini razborit i razuman s obzirom na } \\
\text { okolnosti: } \\
\text { He did not believe it was politic to speak his mind at the time. }\end{array}$ & $6,25 \%$ & $93,75 \%$ \\
\hline & $\begin{array}{l}1.1 \text { arhaično (osoba) razborita i mudra: } \\
\text { Queen Anne was a resolute and politick }{ }^{19} \text { ruler. }\end{array}$ & $17,71 \%$ & $82,29 \%$ \\
\hline Sveukupno politic & & $11,98 \%$ & $88,02 \%$ \\
\hline \multirow[t]{5}{*}{ political } & $\begin{array}{l}1 \text { koji se odnosi na vladu ili javne poslove države: } \\
\text { That was a period of significant political stability in the country. }\end{array}$ & $19,79 \%$ & $80,21 \%$ \\
\hline & $\begin{array}{l}1.1 \text { koji se odnosi na ideje ili strategije određene stranke ili } \\
\text { političke grupacije: } \\
\text { They were slightly opposed to some ideas, but signed the } \\
\text { agreement for purely political reasons. }\end{array}$ & $5,21 \%$ & $94,79 \%$ \\
\hline & $\begin{array}{l}1.2 \text { zainteresiran za ili aktivan u politici: } \\
\text { She has led a very active political life. }\end{array}$ & $13,54 \%$ & $86,46 \%$ \\
\hline & $\begin{array}{l}1.3 \text { motiviran nečijim uvjerenjima ili postupcima koji se } \\
\text { tiču politike: } \\
\text { He was accused of several political crimes. }\end{array}$ & $9,38 \%$ & $90,63 \%$ \\
\hline & $\begin{array}{l}2 \text { derogatorno učinjeno ili postupajući u skladu s interesima } \\
\text { statusa i moći unutar organizacije, a ne u skladu s } \\
\text { principima: } \\
\text { Decisions should not be made on the basis of someone's political } \\
\text { agenda. }\end{array}$ & $3,13 \%$ & $96,88 \%$ \\
\hline $\begin{array}{l}\text { Sveukupno } \\
\text { political }\end{array}$ & & $10,21 \%$ & $89,79 \%$ \\
\hline $\begin{array}{l}\text { Sveukupno politic } \\
\text { i political }\end{array}$ & & $10,71 \%$ & $89,29 \%$ \\
\hline
\end{tabular}

Kadaje riječo paru fantastic-fantastical (v.tablicu 8.), ispitanici sveukupno u značajno većoj mjeri biraju pridjev fantastic $\left(\chi^{2}=172,800 ; p<, 00001\right)$. Također, statistička značajnost utvrđena je u korist izraza fantastic i kod analize svih primjera kojima se predstavljaju značenja pridjeva fantastic $\left(\chi^{2}=121,500\right.$; $p<, 00001)$ te kod onog kojim se predstavlja značenje pridjeva fantastical $\left(\chi^{2}=54,000 ; p<, 00001\right)$. Navedeni rezultati mogli bi ukazivati na to da ispitanici ne razlikuju u potpunosti značenja koja su u OED-u navedena za fantastic od onih koja su navedena za fantastical. Međutim, to ne stoji ako uzmemo u obzir odgovore na rečenicu za značenje fantastic pod 1 i usporedimo taj rezultat $\mathrm{s}$ navodom da se i fantastic i fantastical rabe u značenjima 'nestvaran', maštovit' i 'obilježen živom maštom ili fantazijom', dok je izraz fantastic taj koji se rabi

${ }_{19}$ Arhaični oblik izraza politic koji je u OED-u naveden u rečenici za ovo značenje izraza. 
u kontekstu odobravanja ili pohvale (Kaunisto, 2007: 290). Također, odgovori ispitanika potvrđuju da je pridjev fantastic u suvremenom engleskom jeziku mnogo češći u uporabi (Kaunisto 2007: 290). U obrađenim korpusima izrazi se fantastical job, fantastical amount, fantastic building, fantastical building i fantastical movie ni ne javljaju, dok se ostali javljaju u različitim frekvencijama: fantastic job (BNC (16); COCA (210)), fantastic amount (BNC (1); COCA (15)), fantastic creatures (BNC (2); COCA (23)), fantastical creatures (BNC (2); COCA (12)) i fantastic movie (BNC (0); COCA (16)).

Tablica 8. Distribucija odgovora ispitanika za par "fantastic-fantastical"

\begin{tabular}{|c|c|c|c|}
\hline Pridjev & Značenje pridjeva i rečenica & $-i c$ & -ical \\
\hline \multirow[t]{4}{*}{ fantastic } & $\begin{array}{l}1 \text { neformalno izuzetno dobar ili privlačan: } \\
\text { I am really proud of her because she did a fantastic job with } \\
\text { developing the project. }\end{array}$ & $100 \%$ & $0 \%$ \\
\hline & $\begin{array}{l}1.1 \text { izuzetne veličine ili stupnja: } \\
\text { I told her that she should not have spent such a fantastic amount } \\
\text { of cash on her clothes. }\end{array}$ & $68,75 \%$ & $31,25 \%$ \\
\hline & $\begin{array}{l}2 \text { maštovit ili fantastičan; udaljen od stvarnosti: } \\
\text { His imagination is really fruitful. You will see what I mean once } \\
\text { you read his stories full of fantastic hybrid creatures. }\end{array}$ & $70,83 \%$ & $29,17 \%$ \\
\hline & $\begin{array}{l}2.1 \text { (predmet) koji se čini primjereniji mašti nego } \\
\text { stvarnosti; čudan ili egzotičan: } \\
\text { She had visions of a fantastic, maze-like building. }\end{array}$ & $72,92 \%$ & $27,08 \%$ \\
\hline $\begin{array}{l}\text { Sveukupno } \\
\text { famtastic }\end{array}$ & & $78,13 \%$ & $21,88 \%$ \\
\hline fantastical & $\begin{array}{l}\text { maštovit ili fantastičan; udaljen od stvarnosti: } \\
\text { I enjoyed seeing that fantastical popcorn movie. }\end{array}$ & $87,50 \%$ & $12,50 \%$ \\
\hline $\begin{array}{l}\text { Sveukupno } \\
\text { fantastical }\end{array}$ & & $87,50 \%$ & $12,50 \%$ \\
\hline $\begin{array}{l}\text { Sveukupno } \\
\text { famtastic i } \\
\text { fantastical }\end{array}$ & & $80,00 \%$ & $20,00 \%$ \\
\hline
\end{tabular}

Kada je riječ o paru diabolic - diabolical (v. tablicu 9.), ispitanici se podjednako koriste obama pridjevima, čemu svjedoči činjenica da razlike u sveukupnoj uporabi jednog i drugog pridjeva nisu statistički značajne $\left(\chi^{2}=3,000 ; p=, 08326\right)$. Također, Kaunisto (2007: 290-291) navodi da se jedino izraz diabolical javlja u značenju 'sramotan' ili 'užasan' te da je, prema leksikografskim navodima, u ovome značenju riječ o slengu, neformalnom izrazu karakterističnom za britanski engleski koji se razvio u 20. stoljeću. Odgovori ispitanika na rečenicu u kojoj se pridjev koristi u tome značenju potvrđuju da ispitanici ne razlikuju to značenje.

$S$ obzirom na to da izraz diabolic nije zasebno unesen u mrežno izdanje OED-a, konzultirali smo ostale izvore. U Oxford Advanced Learner's Dictionary of Current English (Hornby, 2000: 346) ne postoji zaseban unos za diabolic, već je unesen pod diabolical pod 2: (rjeđe i diabolic) 'opak i zao; kao vrag'. 
Značenje koje odgovara značenju unesenom pod 2 u mrežnom izdanju OED-a pridruženo je samo izrazu diabolical. Takav bi unos po učestalosti odgovarao Kaunistovu tumačenju (2007: 290). U Longman Exams Dictionary (Bullon, 2006: 408) izraz diabolic nije unesen zasebno već je naznačen samo kao varijanta unosa diabolical, bez naznake učestalosti, i to samo u sljedećem značenju: 'zao ili okrutan'. Značenje koje odgovara značenju unesenom pod 2 u mrežnom izdanju OED-a pridruženo je samo izrazu diabolical. S druge strane, u Webster's Ninth New Colleagiate Dictionary (Mish, 1989: 349) na prvom je mjestu unesen diabolic, a diabolical nakon njega u istom unosu kao varijanta s istim značenjem: 'od, koji se odnosi na ili je karakterističan za vraga'. Ovdje se jedino uneseno značenje preklapa s onim koje je u mrežnom izdanju OED-a navedeno pod 1, što može ukazivati na razlike u naglasku koji različiti leksikografski izvori stavljaju na uporabu u britanskom engleskom i američkom engleskom.

Za razliku od rezultata kod parova politic - political te fantastic fantastical, odgovori ispitanika nisu u skladu s tvrdnjom da je pridjev diabolical u suvremenom engleskom jeziku češći u uporabi (Kaunisto 2007: 290). Također, u obrađenim se korpusima izrazi diabolic plan i diabolic voice ne javljaju, dok se diabolical plan javlja samo u COCA-i (10), a diabolical voice samo u BNC-u (1).

Tablica 9. Distribucija odgovora ispitanika za par "diabolic - diabolical"

\begin{tabular}{|c|l|c|c|}
\hline Pridjev & \multicolumn{1}{|c|}{ Značenje pridjeva i rečenica } & -ic & -ical \\
\hline diabolical & $\begin{array}{l}\text { 1 (i diabolic) karakterističan za vraga ili tako zao da je } \\
\text { sugestivan na vraga: } \\
\text { It felt as if some evil demonic being was trying to include human } \\
\text { beings in its diabolical plan. }\end{array}$ & $52,08 \%$ & $47,92 \%$ \\
\cline { 2 - 4 } & $\begin{array}{l}\text { 2 britanski engleski; neformalno sramotno loš ili neugodan: } \\
\text { The newspaper review described her as a singer with an } \\
\text { absolutely diabolical voice. }\end{array}$ & $60,42 \%$ & $39,58 \%$ \\
\hline $\begin{array}{c}\text { Sveukupno } \\
\text { diabolical }\end{array}$ & & $56,25 \%$ & $43,75 \%$ \\
\hline $\begin{array}{c}\text { Sveukupno } \\
\text { diabolic i diabolical }\end{array}$ & & $56,25 \%$ & $43,75 \%$ \\
\hline
\end{tabular}

Kada je riječ o paru optic - optical (v. tablicu 10.), ispitanici sveukupno u značajno većoj mjeri biraju pridjev optical $\left(\chi^{2}=60,062 ; p<, 00001\right)$. Kod značenja pridjeva optic kako je navedeno u OED-u, ispitanici u nešto većoj mjeri biraju pridjev optical, ali ta razlika nije statistički značajna $\left(\chi^{2}=0,042 ; p=, 83826\right)$. Značajne su razlike $\mathrm{u}$ odgovorima za navedena značenja pridjeva optical, kod kojih ispitanici većinski odabiru upravo optical $\left(\chi^{2}=70,533 ; p<, 00001\right)$. Navedeni rezultati ukazuju na to da ispitanici ne razlikuju u potpunosti značenje koje je u OED-u navedeno za optic od onih koja su navedena za optical. Za razliku od izraza optic atrophy (BNC (4); COCA (19)), u obrađenim 
se korpusima izraz optical atrophy uopće ne javlja, što potvrđuje da se izraz optic u većoj mjeri vezuje uz anatomiju ili medicinu (Kaunisto 2007: 292). To ispitanici ne prepoznaju, s obzirom na to da $\mathrm{u}$ navedenoj kolokaciji podjednako biraju optic i optical. Veću frekvenciju izraza optical potvrđuju i frekvencije drugih kolokacija u BNC-u i COCA-i. U tim se korpusima optic aid, optic principles i optic telescopes uopće ne javljaju, dok su za ostale kolokacije frekvencije sljedeće: optic illusion (BNC (0); COCA (1)), optical illusion (BNC (20); COCA (190)), optical aid (BNC (5); COCA (73)), optical principles (BNC (0); COCA (3)) i optical telescopes (BNC (5); COCA (94)).

Tablica 10. Distribucija odgovora ispitanika za par "optic - optical"

\begin{tabular}{|c|c|c|c|}
\hline Pridjev & Značenje pridjeva i rečenica & $-i c$ & $-i c a l$ \\
\hline optic & $\begin{array}{l}\text { koji se odnosi na oko ili vid: } \\
\text { Sarah was diagnosed with primary optic atrophy. }\end{array}$ & $48,96 \%$ & $51,04 \%$ \\
\hline Sveukupno optic & & $48,96 \%$ & $51,04 \%$ \\
\hline \multirow[t]{5}{*}{ optical } & $\begin{array}{l}1 \text { koji se odnosi na vid, osobito u odnosu na djelovanje } \\
\text { svjetla: } \\
\text { I'm afraid it was just an optical illusion produced by light } \\
\text { manipulation. }\end{array}$ & $17,71 \%$ & $82,29 \%$ \\
\hline & $\begin{array}{l}\text { 1.1 izraden da potpomogne vid: } \\
\text { The doctor told him that he needed some kind of optical aid. }\end{array}$ & $22,92 \%$ & $77,08 \%$ \\
\hline & $\begin{array}{l}1.2 \text { koji se odnosi na znanost o optici: } \\
\text { It is not very difficult to understand the basic optical principles. }\end{array}$ & $44,79 \%$ & $55,21 \%$ \\
\hline & $\begin{array}{l}2 \text { Fizika koji djeluje unutar ili koristi vidljivi dio } \\
\text { elektromagnetskog spektra: } \\
\text { They made frequent use of optical telescopes in their } \\
\text { experiments. }\end{array}$ & $37,50 \%$ & $62,50 \%$ \\
\hline & $\begin{array}{l}\text { 2.1 Elektronika (uređaj) čije djelovanje zahtijeva } \\
\text { elektromagnetsko zračenje: } \\
\text { An optical switch does not function in the same way in which its } \\
\text { electrical predecessor does. }\end{array}$ & $31,25 \%$ & $68,75 \%$ \\
\hline Sveukupno optical & & $30,83 \%$ & $69,17 \%$ \\
\hline $\begin{array}{l}\text { Sveukupno optic i } \\
\text { optical }\end{array}$ & & $33,85 \%$ & $66,15 \%$ \\
\hline
\end{tabular}

\subsection{Diskusija}

Analizirani parovi pridjeva mogu se na temelju prethodnih istraživanja (Gries, 2001; Kaunisto, 2007; Marsden, 1985, kako je navedeno u Lipka, 1992: 167) uvjetno podijeliti na one kod kojih je razlika u značenju jasnija te na one kod kojih je frekvencija uporabe jednog pridjeva u paru izraženija. Takva je podjela nužno uvjetna zato što se i kod pojedinih parova kod kojih je jedan pridjev u paru značajnije učestaliji može govoriti o određenoj razlici u značenju između dva pridjeva (primjerice, u slučaju para politic - political). Kada je riječ o razlikovanju značenja pridjeva u paru, sudovi se donose ne samo na temelju njihova razlikovanja u leksikografskim izvorima, već i 
analizom vrsta kolokacija u kojima se javljaju (v. Gries, 2001; Gries, 2017; Kaunisto, 2007). Stoga se zaključci o mjeri u kojoj se značenja pojedinih pridjeva razlikuju i mjeri u kojoj ih ispitanici prepoznaju nužno donose za svaki par pojedinačno.

$\mathrm{Na}$ temelju rezultata istraživanja možemo zaključiti da ispitanici relativno uspješno odabiru ispravan pridjev u slučajevima u kojima je jasna razlika između značenja dva pridjeva u paru. To je, primjerice, vidljivo kod njihova razlikovanja značenja kod classic - classical (primjerice, u kolokacijama classic car i classic symptoms, a u usporedbi s classical architecture i classical ballet). S druge strane, kod para historic - historical ispitanici ne razlikuju određenje nečega što pripada prošlosti od određenja nečega što je (potencijalno) slavno ili bitno u prošlosti (primjerice, $\mathrm{u}$ kolokaciji historic sites $\mathrm{u}$ usporedbi s historical evidence). Ispitanici se uspješno koriste pridjevima $\mathrm{u}$ fiksnim frazama (be economical with the truth) te kada se koriste u prenesenom značenju (The atmosphere was electric (...)). Uspješnost razlikovanja ovisi i o izloženosti kolokacijama, odnosno učestalosti uporabe. Sukladno tome, iznimke većinski ispravnom odabiru pridjeva predstavljaju kolokacije kao što je classical field theory, a u kojima se pridjev javlja u kolokaciji koja ima usko značenje (u ovom slučaju vezano za područje fizike) i kojoj ispitanici najvjerojatnije nisu bili izloženi u onoj mjeri u kojoj je to slučaj s kolokacijama u kojima se pridjev rabi u jednom od širih značenja. Važnost učestalosti uporabe očita je i u analizi kolokacija poput electric cooker, gdje se pridjev na -ic rabi u vrlo bliskom značenju kao i pridjev na -ical $\mathrm{u}$ jednom od svojih značenja, ali gdje konzultirani korpusi engleskoga jezika kao i odgovori ispitanika upućuju na učestalost uporabe.

Budući da izbor pridjeva u paru ovisi i o frekvenciji njihove uporabe, procjena stupnja razlikovanja značenja predstavlja veći izazov kod parova kod kojih je jedan pridjev u značajnije većoj uporabi. Tako se, primjerice, nerazlikovanje značenja politic i political među ispitanicima nužno mora sagledavati u odnosu na činjenicu da je izraz politic značajnije rjeđe u uporabi u usporedbi s political. Kada je riječ o parovima pridjeva za koje Kaunisto (2007) potvrđuje da je jedan pridjev u engleskome jeziku značajnije češći u uporabi, ispitanici većinski odabiru upravo taj pridjev za koji se smatra da je češći u uporabi. Iznimku predstavljaju izbori ispitanika kod para diabolic diabolical, a u slučaju ovoga para može se uočiti i razlika u naglasku koji je u različitim rječnicima stavljen na uporabu navedenih pridjeva u britanskom engleskom i američkom engleskom. 


\section{ZAKLJUČAK}

Širenje engleskoga jezika i njegov trenutačni status doveli su do promjena $\mathrm{u}$ učestalosti njegove uporabe $\mathrm{u}$ zemljama $\mathrm{u}$ kojima se tradicionalno smatra stranim jezikom. U tome kontekstu možemo govoriti o sve većim zahtjevima razine znanja engleskoga jezika koja se očekuje od osoba koje se redovito njime koriste, a posebice od studenata anglistike. Cilj je ovoga rada opisati uporabu engleskih pridjeva na -ic i -ical te utvrditi mjeru u kojoj neizvorni govornici engleskoga jezika razlikuju njihova značenja. Odabir pridjeva kao i analiza temeljnih značenjskih razlika među njima temelji se ponajprije na monografiji koju je 2007. godine objavio Mark Kaunisto. S obzirom na to da engleski pridjevi na -ic i -ical predstavljaju značenjski bliske i strukturno slične izraze, razlikovanje njihovih značenja predstavlja izazov ne samo za govornike engleskoga jezika, već i za jezikoslovce koji takve razlike nastoje utvrditi i opisati. Stoga je za potrebe istraživanja bilo potrebno osloniti se i na dodatne izvore koji svjedoče o mjeri u kojoj možemo govoriti o razlikama u značenju između takvih pridjeva, a s obzirom na to da se zaključci o razlikama između njihovih značenja nerijetko donose na temelju analize jezičnoga okruženja u kojima se pojedini pridjev rabi (v. Gries, 2001; Kaunisto, 2007). $\mathrm{U}$ analizi prikupljenih podataka koristili su se i BNC te COCA korpusi, što doprinosi donošenju zaključaka o razlikovanju značenja obrađenih pridjeva među studentima anglistike. Kod pojedinih je pridjeva na -ic i -ical moguće utvrditi jasnu značenjsku razliku. Nju u većini slučajeva takvih pridjeva potvrđuju i frekvencije kolokacija u obrađenim korpusima pa tada možemo govoriti o razlikama u uporabi koje se temelje na značenjskoj razlici i frekvenciji uporabe. Međutim, u slučajevima kada značenjska razlika nije jasna, upravo će frekvencija uporabe biti odlučujući čimbenik u utvrđivanju razlika.

Rezultati istraživanja potvrđuju pretpostavku da uspješnost razlikovanja značenja engleskih pridjeva na -ic i -ical ovisi ponajprije o razlici između njihovih značenja, učestalosti uporabe te jezičnome okruženju u kojem se pridjev rabi. U budućim bi se istraživanjima engleskih pridjeva na -ic i -ical posebna pozornost mogla posvetiti znatno većem broju kolokacija, pri čemu bi se razlikovanje značenja i uporaba takvih pridjeva mogli istražiti kroz najrecentnije podatke o učestalosti uporabe koji su dostupni u različitim korpusima te daljnjim istraživanjima među izvornim i neizvornim govornicima engleskoga jezika.

\section{LITERATURA}

Bullon, S. (gl. i odg. ur.) (2006) Longman Exams Dictionary. Harlow: Pearson Education Limited. British National Corpus. https://www.english-corpora.org/bnc/ (17. 9. 2019.).

Cabredo Hofherr, P. (2010) Adjectives: An introduction. U Cabredo Hofherr, P. i Matushansky, O. (ur.) Adjectives: Formal Analyses in Syntax and Semantics. Amsterdam i Philadelphia: John Benjamins, 1-26. 
Cinque, G. (2010) The Syntax of Adjectives: A Comparative Study. Cambridge, MA: The MIT Press. Corpus of Contemporary American English. https://www.english-corpora.org/COCA-i/ (17. 9. 2019.).

Cruse, A. D. (1986) Lexical Semantics. Cambridge: Cambridge University Press.

Cruse, A. D. (2000) Meaning in Language: An Introduction to Semantics and Pragmatics. Oxford: Oxford University Press.

Cruse, A. D. (2017) The lexicon. U Aronoff, M. i Rees-Miller, J. (ur.) The Handbook of Linguistics $(2$. izdanje). Hoboken, NJ: Wiley-Blackwell, 235-254.

Gledhill, C. J. (2000) Collocations in Science Writing. Tübingen: Gunter Narr Verlag Tübingen.

Gries, S. Th. (2001) A corpus-linguistic analysis of English -ic vs -ical adjectives. ICAME Journal 25, 65-108. http://clu.uni.no/icame/ij25/index.html (15. 5. 2019.).

Gries, S. Th. (2017) Quantitative Corpus Linguistics with R: A Practical Introduction (2. izdanje). New York: Routledge.

Hornby A. S. (2000) Oxford Advanced Learner's Dictionary of Current English (6. izdanje). Wehmeier, S. (ur.) i Ashby, M. M. (fon. ur.). Oxford: Oxford University Press.

Howarth, P. (1998) The phraseology of learners' academic writing. U Cowie, A. P. (ur.) Phraseology: Theory, Analysis, and Applications. Oxford: Clarendon Press, 161-186.

Kaunisto, M. (2007) Variation and Change in the Lexicon: A Corpus-Based Analysis of Adjectives in English Ending in -ic and -ical. Amsterdam i New York: Rodopi.

Lipka, L. (1992) An Outline of English Lexicology: Lexical Structure, Word Semantics, and Word-Formation (2. izdanje). Tübingen: Max Niemeyer Verlag.

Matthews, P. H. (2014) The Position of Adjectives in English. Oxford: Oxford University Press.

Men, H. (2018) Vocabulary Increase and Collocation Learning: A Corpus-Based Cross-sectional Study of Chinese Learners of English. Singapore: Springer i Shangai Jiao Tong University Press.

Mihaljević Djigunović, J. i Geld. R. (2002) English in Croatia today: Opportunities for incidental vocabulary acquisition. Studia Romanica et Anglica Zagrabiensia 47-48, 335-352. https://hrcak. srce.hr/index.php?show=clanak\&id_clanak_jezik=33116 (15. 5. 2019.).

Mish, F. C. (gl. ur.) (1989) Webster's Ninth New Collegiate Dictionary. Springfield, MA: Merriam-Webster.

Murphy, M. L. (2010) Lexical Meaning. Cambridge: Cambridge University Press.

Nesselhauf, N. (2003) The use of collocations by advanced learners of English and some implications for teaching. Applied Linguistics 24 (2), 223-242.

Nesselhauf, N. (2005) Collocations in a Learner Corpus. Amsterdam i Philadelphia: John Benjamins.

Oxfordov rječnik engleskoga jezika. https://en.oxforddictionaries.com/english (15. 2. 2019.).

Palmer, F. R. (1981) Semantics: A New Outline (2. izdanje). Cambridge: Cambridge University Press.

Sleeman, P., Van de Velde, F. i Perridon, H. (ur.) (2014) Adjectives in Germanic and Romance. Amsterdam i Philadelphia: John Benjamins.

Suau Jiménez, F. (2008) Semantics. U Fuster, M. i Sánchez, A. (ur.) Working with Words: An Introduction to English Linguistics. València: Universitat de València, 141-180.

Tucker, G. H. (1998) The Lexicogrammar of Adjectives: A Systemic Functional Approach to Lexis. London i New York: Cassell.

Zergollern-Miletić, L. (2008) Kategorija određenosti i neodređenosti u engleskom i hrvatskom jeziku. Doktorska disertacija. Zagreb: Filozofski fakultet Sveučilišta u Zagrebu. https://www.bib.irb. $\mathrm{hr} / 397545$ (8. 5. 2019.). 


\section{DISTINGUISHING BETWEEN THE MEANINGS OF ENGLISH ADJECTIVES IN -IC AND -ICAL AND THEIR USE AMONG CROATIAN SPEAKERS OF ENGLISH}

English as a lingua franca has been studied from various viewpoints and in different contexts. Such analyses include, among other issues, aspects of English language learning and use among non-native speakers in contexts in which English is traditionally taught and used as a foreign language. This paper deals with the investigation of the differences in meaning and use of adjectives in -ic and -ical among Croatian speakers of the English language. The aim is to describe the use of such adjectives and identify the extent to which non-native speakers distinguish between their meanings. The choice of the adjectives and the overview of the differences in meaning among them are based primarily on the monograph published by Mark Kaunisto in 2007 and the online edition of the Oxford dictionary of the English language. The research, which included the administration of a test, was conducted in March and April 2019 among ninety-six Croatian students of English. The results of the research suggest that the differentiation between the meanings of the English adjectives in -ic and -ical depends primarily on the differences in meanings of the analysed adjectives, the frequency of use of a specific adjective in the English language, as well as on the linguistic context in which the adjective is used.

Keywords: the English language, adjectives in -ic and-ical, collocations, synonymy, non-native speakers. 